\title{
Idrætshistorisk aktivitetscenter på Den jyske Idrætsskole?
}

\author{
af Jens Topholm \& Ole Worm
}

Indsamlingsarbejdet i forbindelse med udstillingen „Sport i Vejle“ i 1984 på Vejle kulturhistoriske Museum (VKM) og tilkendegivelser fra de lokale idrætsforeninger afdækkede en række behov, som museet ønsker at arbejde videre med. De lokale idrætsforeninger savner viden om deres fortid for at forstå deres nuværende situation, og det er på høje tid at sætte ind med systematisk indsamling af idrætshistorisk materiale.

I august 1984 henvendte Den jyske Idrætsskole (DJI) sig til VKM med forslag om at fastholde udstillingen på skolen, når den udløb på museet. Heraf voksede ideen frem om et idrætshistorisk aktivitetscenter.

Idræt og sport er en kompleks del af vort kulturliv med en lang historie og en bred folkelig basis. Hver dag skrives der en lille historie i enhver idrætsforening, idet alle menneskelige handlinger - her idrætshandlinger er brikker i en historisk sammenhæng, hvis hovedtendenser bør bevares og udstilles for eftertiden. Jo tættere man kommer aktøren, jo mere folkelig bliver historien, og jo mere vedkommende vil den blive for os.

Det er et forsømt kulturelt arbejdsområde, hvor både de kulturhistoriske museer/arkiver og de idrætslige organisationer og institutioner $i$ for ringe grad har sikret idrætshistorisk materiale for eftertiden. Formidlingen - i form af udstillinger, undersøgelser m.v. er for sparsom og traditionel.

Vi mener, at idrætshistorien hører til ude $\mathrm{i}$ foreningen - hos de enkelte idrætsudøvere. Historie er imidlertid også et håndværk. Det er faktisk en kompliceret sag at sætte sig for at grave i en forening eller et områdes idrætshistorie, og de ting, man finder frem, kan få stor betydning for foreningens dagligdag. Ved dette håndværksarbejde er det nødvendigt at komme ud over ,,skåltalerne“" og ,foreningen længe leve“"

På denne baggrund vil vi afprøve en nyskabelse, hvor hovedideen er, at den faglige museale ekspertice integreres $\mathrm{i}$ en idrætshøjskole, hvor idræt faktisk udøves og behandles pædagogisk. Vi tror, at der i dette faglige og pædagogiske miljø kan skabes nye muligheder for at beskæftige sig med idrætten som kulturfænomen.

En anden hovedidé er, at det idrætshistoriske aktivitetscenter gøres regionalt. Inden for det næste par år oprettes sandsynligvis et landsdækken- 
de museum for idræt. Vi mener, at et sådant specialmuseum p.g.a. idrættens differentierede og brede fundering må have en række regionale støttepunkter - f.eks. i form af idrætshistoriske aktivitetscentre, der kan formidle de helt afgørende lokale kontakter til organisationer, museer m.v. og samtidig specialisere sig inden for bestemte fagområder. Disse centre bør være en integreret del af et kommende idrætsmuseum.

Det idrætshistoriske aktivitetscenters hovedopgave vil være:

1. udstillingsvirksomhed

2. indsamlingsvirksomhed

3. oplysningsvirksomhed

4. undersøgelsesvirksomhed

dvs. at vi altid vil have en basisudstilling på Den jyske Idrætsskole, og at vi gerne vil etablere lokale udstillinger i de enkelte kommuner og foreninger.

Indsamlingsvirksomheden organiseres i samarbejde med de lokale foreninger. Det er vor tanke, at det idrætshistoriske aktivitetscenter skal være forum for studiekredse og foredragsrækker.

En egentlig undersøgelses- og forskningsvirksomhed har de øvrige aktiviteter som forudsætning. Hovedområdet for forskningen skal være idræt og lokalhistorie. Denne virksomhed må etableres bredt, således at der både foretages dybtgående undersøgelser af udvalgte emner og ydes faglig bistand ved udarbejdelse af jubilæumsskrifter o.l. 